\title{
AUDIOLOGICAL EVALUATION OF TRAUMATIC BRAIN INJURY - A CASE STUDY
}

\section{Caroline Donadon ${ }^{1,2, A-F}$, Natalia Ferrazoli ${ }^{1,2, A, B, D-E}$, Reinaldo Gusmão ${ }^{1, A}$, Adriano Rezende ${ }^{1, A, G}$, Piotr H Skarzynski ${ }^{3-5, A, E, G}$, Daniela Capra ${ }^{6,7, C, F}$, Milaine Sanfins $\mathbf{s}^{1,7, A, B, D-E}$}

\author{
${ }^{1}$ Audiology Department, Clinica Respirare, Brazil \\ ${ }^{2}$ School of Medical Sciences, University of Campinas, Brazil \\ 3 Department of Teleaudiology and Hearing Screening, World Hearing Center, \\ Institute of Physiology and Pathology of Hearing, Poland \\ Poland \\ ${ }^{5}$ Institute of Sensory Organs, Warsaw, Poland \\ ${ }^{6}$ Instituto Nacional de Neurociência Translacional, Universidade \\ Federal do Rio de Janeiro, Brazil \\ ${ }^{7}$ Centro de Eletrofisiologia e Neuroaudiologia Avançada, Brazil
}

${ }^{4}$ Department of Heart Failure and Cardiac Rehabilitation, Medical University of Warsaw,

Corresponding author: Caroline Donadon; Audiology Department,

Clinica Respirare, Rua Goncalves Cesar, 146, 13073-230, Campinas, Brazil;

email: carol_donadon@hotmail.com

\begin{abstract}
Background: Traumatic brain injury (TBI) is a pathology frequently causing mortality or serious sequelae. About $20 \%$ of individuals with TBI will have some degree of auditory alteration. The aim of the present study was to use behavioural and electrophysiological assessments to analyse the hearing of a patient with TBI.

Case report: A young male adult who had suffered severe TBI caused by a motorcycle accident was evaluated. The patient underwent a peripheral hearing evaluation and electrophysiological assessment. Pure tone audiometry revealed profound sensorineural hearing loss in the left ear and normal hearing in the right. In the electrophysiological assessment, an ABR click test showed the presence of a response in the right ear at $80 \mathrm{~dB} H \mathrm{HL}$ but no response in the left ear at $90 \mathrm{~dB}$ HL. Evaluation of the Middle Latency Response revealed the presence of both an electrode effect (C3) and an ear effect (A1). The P300 wave showed an event-related potential within normal limits in the right ear and no responses in the left.

Conclusions: The present case study verifies the importance of assessing the peripheral and central auditory nervous system in cases of patients with a history of TBI. It reinforces the need for diagnosis and audiological monitoring of these patients.
\end{abstract}

Key words: traumatic brain injury $\bullet$ electrophysiology $\bullet$ hearing $\bullet$ evoked potentials $\bullet$ auditory pathways

\section{OCENA AUDIOLOGICZNA URAZOWEGO USZKODZENIA MÓZGU}

\section{- STUDIUM PRZYPADKU}

\section{Streszczenie}

Wstęp: Urazowe uszkodzenie mózgu (TBI) jest patologią często powodującą śmiertelność lub poważne następstwa. U około 20\% osób z TBI występują zmiany słuchowe. Celem niniejszego badania było wykorzystanie oceny behawioralnej i elektrofizjologicznej do analizy słuchu pacjenta z TBI.

Opis przypadku: Zbadano młodego dorosłego mężczyznę, który doznał ciężkiego TBI w wyniku wypadku motocyklowego. Pacjenta poddano ocenie słuchu obwodowego i ocenie elektrofizjologicznej. Audiometria tonalna ujawniła głęboki niedosłuch odbiorczy w lewym uchu i prawidłowy słuch w prawym. W ocenie elektrofizjologicznej test ABR wykazał obecność odpowiedzi w prawym uchu przy 80 dB HL, ale brak odpowiedzi w lewym uchu przy 90 dB HL. Ocena odpowiedzi o średniej latencji ujawniła obecność zarówno efektu elektrodowego (C3), jak i efektu ucha (A1). Fala P300 wykazała potencjał związany ze zdarzeniem w normalnych granicach w prawym uchu i brak odpowiedzi w lewym.

Wnioski: Niniejsze studium przypadku potwierdza znaczenie oceny ośrodków słuchowych obwodowego i centralnego układu nerwowego u pacjentów z TBI. Potwierdza także potrzebę diagnostyki i audiologicznego monitorowania tych pacjentów.

Słowa kluczowe: urazowe uszkodzenie mózgu • elektrofizjologia • słuch • potencjały wywołane • droga słuchowa

\section{Background}

Traumatic brain injury (TBI) is a pathology that frequently causes mortality or serious sequelae. In developed countries such as the United States it is estimated that about 1.4 million people each year are affected by TBI [1]. Research indicates that the lower the income of the population the higher the incidence of TBI; in Latin America the incidence rate is around 150 per 100,000 individuals [2].

TBI is one of the leading causes of death and disability worldwide, notably in Brazilian cities. Although the leading causes 
Table 1. Results of pure tone threshold audiometry

\begin{tabular}{|c|c|c|c|c|}
\hline Parameter & ECochG & Click ABR & MLAEP & LLAEP \\
\hline Equipment & Biologic Navigator Pro & Biologic Navigator Pro & Biologic Navigator Pro & Biologic Navigator Pro \\
\hline Stimulated ear & RE/LE & RE/LE & RE/LE & RE/LE \\
\hline Type of stimulus & Click & Click & Click & Tone burst \\
\hline Polarity of stimulus & Alternating & Rarefaction & Rarefaction & Alternating \\
\hline Intensity of stimulus & $90 \mathrm{~dB} \mathrm{nHL}$ & $80 \mathrm{~dB} n \mathrm{~nL}$ & $80 \mathrm{~dB}$ & $75 \mathrm{~dB} \mathrm{nHL}$ \\
\hline Rate of stimulus & $10.3 / \mathrm{sec}$ & $19.3 / \mathrm{sec}$ & $9.1 / \mathrm{sec}$ & $1.1 / \mathrm{sec}$ \\
\hline Number of scans & 1000 & 2000 & 1000 & 300 \\
\hline Filter $(\mathrm{Hz})$ & $10-1500$ & $100-1500$ & $30-1500$ & $1-30$ \\
\hline Window & $10.66 \mathrm{~ms}$ & $10.66 \mathrm{~ms}$ & $106.6 \mathrm{~ms}$ & $533 \mathrm{~ms}$ \\
\hline Transducer & $\begin{array}{c}\text { Insert ER-3A (Natus } \\
\text { Medical) }\end{array}$ & Insert ER-3A & Insert ER-3A & Insert ER-3A \\
\hline Position of electrodes & TM electrode, A1 and A2 & $\mathrm{Fz}, \mathrm{A} 1$, and $\mathrm{A} 2$ & $\mathrm{C} 1, \mathrm{C} 2, \mathrm{Fpz}, \mathrm{A} 1$, and $\mathrm{A} 2$ & $\mathrm{Cz}, \mathrm{Fpz}, \mathrm{Fz}, \mathrm{A} 1$, and $\mathrm{A} 2$ \\
\hline
\end{tabular}

Key: RE, right ear; LE, left ear; ms, milliseconds; sec, second; ABR, auditory brainstem response; MLAEP, middle latency auditory evoked potential; LLAEP, long latency auditory evoked potential

of TBI varies by country, in Brazil motor vehicle accidents are responsible for most TBI cases. Individuals who survive TBI often have sequelae that interfere with their quality of life and well-being; TBI also causes difficulties for people around them such as family members and caregivers [3].

As a result of TBI, the most commonly affected regions are the head and neck, and individuals may present visual and auditory dysfunction, vertigo, ataxia, dysarthria, paresthesia, vertigo, drop attacks, weakness, or cognitive impairment [4]. Regarding auditory impairments, it is known that about $20 \%$ of individuals will experience some degree of auditory alteration after TBI, with hearing loss and tinnitus being the most prevalent otological manifestations $[5,6]$. Tinnitus may be associated with an electrophysiological dysfunction in the cochlea, auditory nerve, or even in the central auditory nervous system [7].

In view of the high prevalence of auditory impairment after a TBI, it is extremely important that otorhinolaryngological and audiological assessments are made which can fully diagnose and monitor the auditory abilities of these individuals. Auditory alterations interfere directly with the individual's communication and social skills.

There have only been a few studies that have aimed at describing the audiological status of individuals suffering from TBI. The aim of the present study was to examine the case of TBI caused by a motorcycle accident and analyse the patient's peripheral hearing and perform electrophysiological assessments. Peripheral hearing was tested via pure tone audiometry and tympanometry (impedance measurement and testing of ipsilateral and contralateral acoustic reflexes); electrophysiological assessment was made in terms of auditory brainstem response, middle latency response, and long latency response.

\section{Case presentation}

This study was approved by the Research Ethics Committee (protocol number 2.831.741). Data were collected in November 2018. Informed consent for research was obtained from the participant after an explanation of the nature, purpose, and expected results of the study.

The young adult male, 31 years old, had suffered severe TBI caused by a motorcycle accident. According to medical records, the accident that caused the injury occurred in April 2008. The patient was admitted with a severe TBI (8 points) based on the Glasgow Coma Scale (GCS), with injury to the frontal, temporal, and parietal lobes, visible in a cranial CT. He underwent a decompressive frontotemporo-parietal craniectomy due to an epidural haemorrhage. Then, to treat cranial deformity, a late frontal parietal cranioplasty was performed to correct the bone on the left side.

During the ICU recovery, the patient developed a liquoric fistula, which was surgically corrected, and sequelae of hemiparesis on the right side, aphasia, hyposmia, and profound hearing loss in the left ear. After the cranioplasty, the audiological clinical picture indicated normal hearing in the right ear and profound sensorineural hearing loss in left. After the recommended treatments, the patient showed clinical improvements, with the only complaint being hearing loss.

Some 5 months after the accident he was referred for audiological and ENT evaluation due to a complaint of unilateral hearing loss (left ear) associated with symptoms of Eustachian tube dysfunction. An audiological evaluation was performed and consisted of pure tone thresholds and electrophysiological assessment.

Pure tone audiometry (PTA) involved air conduction thresholds from 250 to $8000 \mathrm{~Hz}$ and bone conduction thresholds from 500 to $4000 \mathrm{~Hz}$. Since the patient had profound sensorineural hearing loss in his left ear and normal hearing in his right ear, air and bone conduction thresholds in the left ear were obtained with contralateral air conduction masking (white noise). Due to the presence of a cranial prosthesis, bone conduction thresholds were obtained with a B71 bone vibrator in the Fpz position. PTA was 

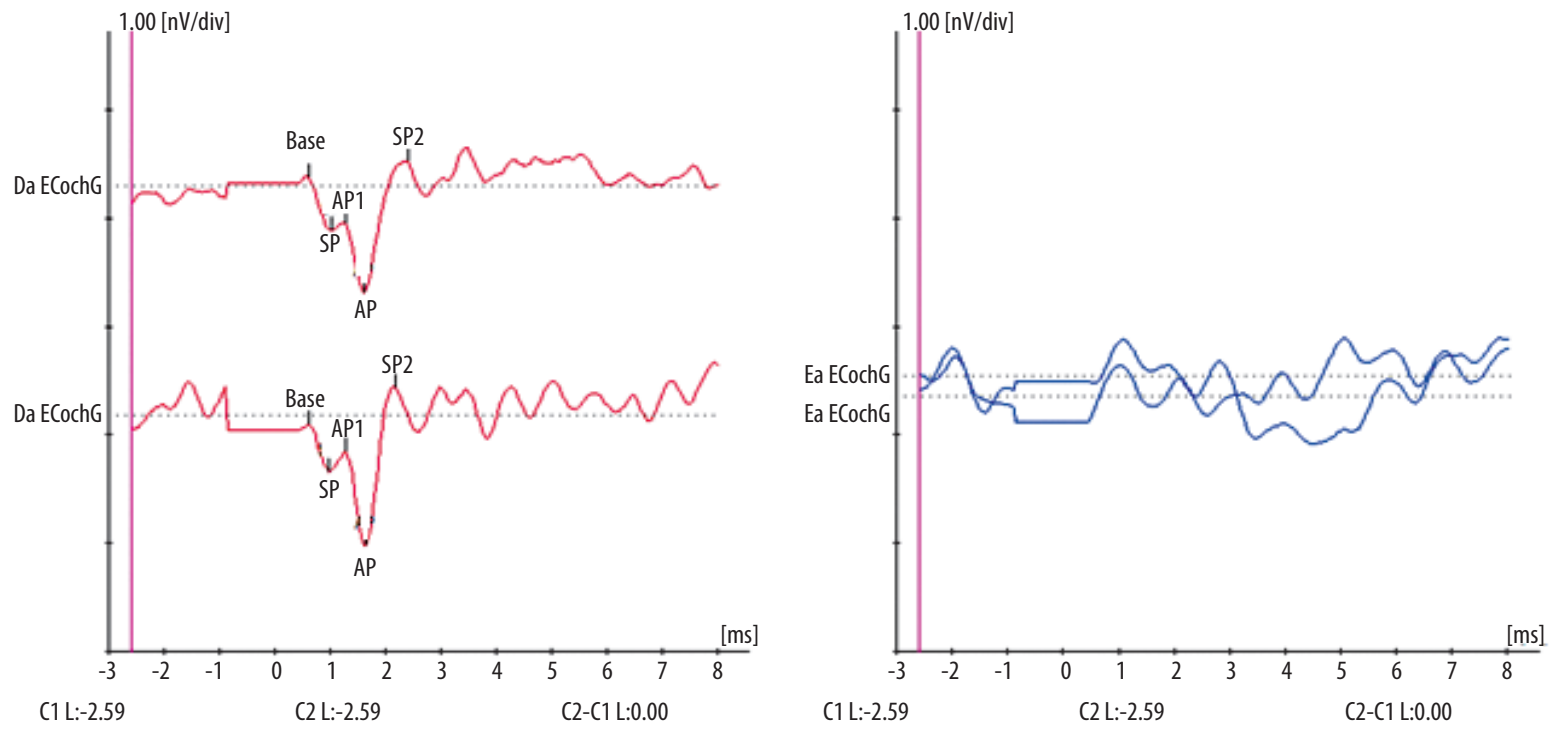

Figure 1. Electrocochleography responses (red, left ear; blue, right ear) in the patient (adult, 31 y.o.) after severe TBI
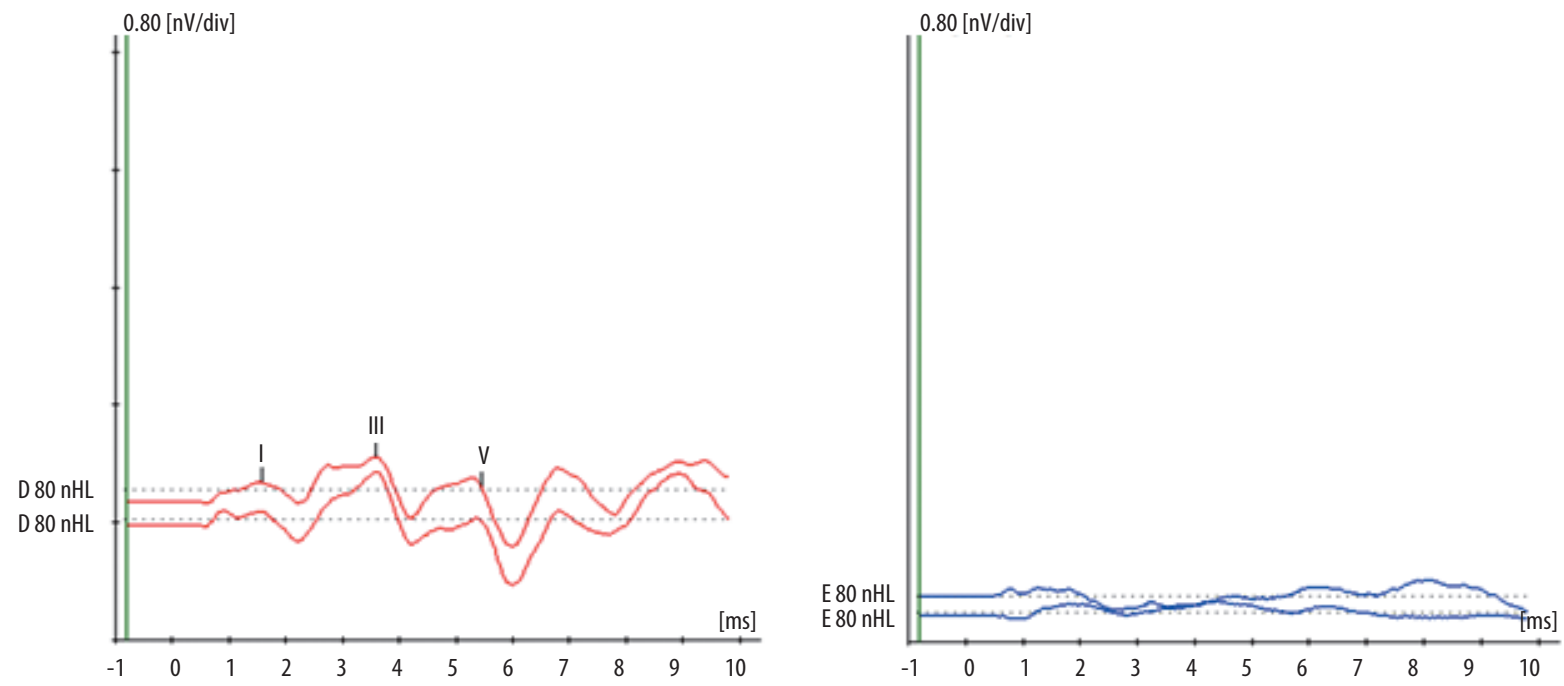

Figure 2. Click Auditory Brainstem Responses (red, right ear; blue, left ear)

done in a sound-treated booth via a Beta 6000 audiometer (Beta Medical) and TDH-39 phones, according to adopted criteria [10].

Electrophysiological evaluation was conducted using Biologic Navigator Pro equipment (Natus, USA) in an acoustically prepared soundproof and electrically screened room. The subject remained seated in a reclining chair in a comfortable position. The skin was cleaned with abrasive paste after which electrodes were placed with electrolytic paste and adhesive tape. The impedance was kept below $3 \mathrm{k} \Omega$ and the inter-electrode impedance less than $2 \mathrm{k} \Omega$. Testing was performed monaurally for the right ear and left ear separately and involved four procedures, as follows.

(i) Electrocochleography

Electrocochleography used clicks of $90 \mathrm{~dB}$ HL, with reference and ground electrodes placed in mastoid plugs.
The active electrode (extra-tympanic TM-Wick) was placed in contact with the tympanic membrane and maintained in position by an insert phone placed in the external auditory canal.

Electrocochleography of the right side showed a ratio of summating potential (SP) to action potential (AP) amplitudes of $39 \%$ and ratio of SP area to AP area (aSP/aAP) of 1.91 (Figure 1). The results were $46 \%$ for SP/AP and 2.43 for aSP/aAP - within the normal range described by Coats [11] and Baba [12]. No responses were observed in the left ear.

\section{(ii) Click Auditory Brainstem Response (Click ABR)}

To investigate the integrity of the auditory pathway, click $\mathrm{ABR}$ was performed at an intensity of $80 \mathrm{~dB} \mathrm{HL}$. The results were compared with the normal values set by the Bio-logic Navigator Pro $[13,14]$. Waves I, III, and V were present in the right ear $(\mathrm{I}=1.70, \mathrm{III}=3.89, \mathrm{~V}=5.76 \mathrm{~ms})$, which were 
within normal limits (Figure 2). There were no responses in the left ear

(iii)Middle Latency Auditory Evoked Potential (MLAEP)

Using MLAEP, traces obtained under different conditions of ear or electrode were compared with the normal values established by Musiek and Lee [13]. The different conditions were:

a) Electrode effects reflect the difference in amplitude between the two electrodes when stimulating just one ear or both ears;

b) The effect of the ear reflects the difference in amplitude between the right and left ears.

The latency and amplitude of the $\mathrm{Na}$ and $\mathrm{Pa}$ waves, as well as the inter-latency and inter-amplitude values of the $\mathrm{Na}-\mathrm{Pa}$ components, were evaluated. This study was based on a cut-off of $50 \%$, so $\mathrm{Na}-\mathrm{Pa}$ amplitudes that presented a difference greater than $50 \%$ were considered as altered responses. Normally, the electrodes are positioned in the right (C4) and left (C3) coronal regions; however, in the present case, due to the presence of the cranial prosthesis, the electrodes were relocated to $\mathrm{C} 2$ and $\mathrm{C} 1$. Thus, for the analysis of the electrode effect, the responses of $\mathrm{C} 1 \mathrm{~A} 1 \times \mathrm{C} 2 \mathrm{~A} 1$ and $\mathrm{C} 1 \mathrm{~A} 2 \times \mathrm{C} 2 \mathrm{~A} 2$ were considered, while the responses of $\mathrm{C} 1 \mathrm{~A} 1 \times \mathrm{C} 1 \mathrm{~A} 2$ and $\mathrm{C} 2 \mathrm{~A} 1 \times \mathrm{C} 2 \mathrm{~A} 2$ were considered for the analysis of ear effects.

Figure 3 and Table 4 show the MLAEP responses, which indicate altered responses for both the electrode effect (left hemisphere) and the ear effect (left ear).

(iv) Long Latency Auditory Evoked Potential (LLAEP)

LLAEP was recorded by presenting two acoustic stimuli, one being elicited regularly and the other randomly. The less frequent (rare) stimulus was presented at a frequency of $2000 \mathrm{~Hz}$ (60 stimuli) and the frequent stimulus at $1000 \mathrm{~Hz}$ (240 stimuli). The patient was instructed to direct their attention to the rare stimulus that was randomly presented. The results were compared with the normal values established by McPherson [14]. The P300 wave was present in the right ear at a latency of $310.5 \mathrm{~ms}$ and amplitude of $3.01 \mu \mathrm{V}$, which were within normal values (Figure 4). There were no responses in the left ear.
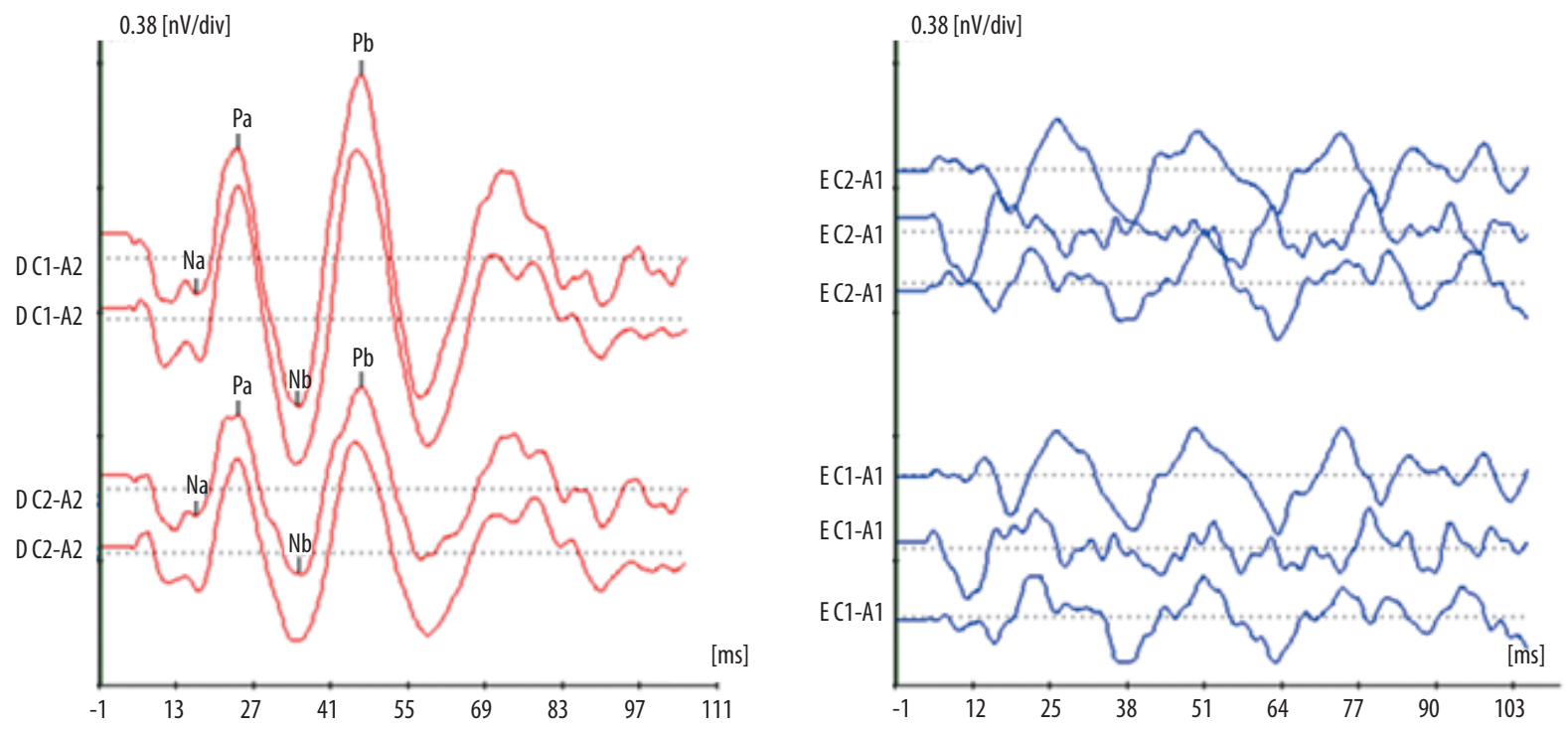

Figure 3. Middle Latency Auditory Evoked Potentials (MLAEP) responses for the right ear (red) and left ear (blue)

Table 2. Middle Latency Auditory Evoked Potential Responses

\begin{tabular}{|c|c|c|c|c|c|c|}
\hline \multirow{2}{*}{ Magnitudes } & \multicolumn{2}{|c|}{$\mathrm{Na}$} & \multicolumn{2}{|c|}{$\mathrm{Pa}$} & \multicolumn{2}{|c|}{$\mathrm{Na}-\mathrm{Pa}$} \\
\hline & Lat (ms) & $\operatorname{Amp}(\mu \mathrm{V})$ & Lat (ms) & $\operatorname{Amp}(\mu \mathrm{V})$ & Interlatency & Interamplitude \\
\hline $\mathrm{C} 1 \mathrm{~A} 2$ & 16.69 & 0.11 & 24.18 & 0.34 & 7.50 & 0.45 \\
\hline $\mathrm{C} 2 \mathrm{~A} 2$ & 16.60 & 0.08 & 24.18 & 0.22 & 7.50 & 0.30 \\
\hline C1A1 & \multicolumn{2}{|c|}{ ABS } & \multicolumn{2}{|c|}{$A B S$} & - & - \\
\hline $\mathrm{C} 2 \mathrm{~A} 1$ & \multicolumn{2}{|c|}{ ABS } & \multicolumn{2}{|c|}{ ABS } & - & - \\
\hline
\end{tabular}

Key: Lat, latency; Amp, amplitude; ms, milisecond; $\mu \mathrm{V}$, microvolts, $\mathrm{C} 1 \mathrm{~A} 2$, left hemisphere $\mathrm{x}$ right ear; $\mathrm{C} 2 \mathrm{~A} 2$, right hemisphere $\mathrm{x}$ right ear; $C 1 A 1$, left hemisphere $x$ left ear; $C 2 A 1$, right hemisphere $x$ left ear; $A B S$, absence of response 
The acquisition parameters for all the electrophysiological tests used in this study are shown in Table 3.

\section{Discussion}

The trauma of TBI often causes damage to the central auditory nervous system (CANS). In the present study, the auditory responses of a 31-year-old adult male patient who suffered TBI after a motorcycle accident were analysed. The literature indicates that TBI events are greatest in adult males and are often the result of serious traffic accidents, whether by car, motorcycle, or bicycle.

After the accident, the rescue service found the victim unconscious and in view of the severity of the clinical picture he was referred to the intensive care unit. In the ICU, primary lesions (physical damage caused by impact) and secondary ones (physiological responses by undamaged cells due to primary lesions) were found [15].

Audiological findings in patients with TBI are extremely rare. However, hearing impairment may result from alterations in any part of the auditory pathway (external ear, middle ear, inner ear, cranial nerve, trunk, or subcortical and cortical regions). According to Chiasson [16], TBI can cause a series of hearing losses that may include cochlear losses, vestibular alterations, and central auditory modifications.

After discharge from hospital, the patient was referred for otorhinolaryngological evaluation due to lowered auditory sensitivity and tinnitus in the left ear. The complaint was
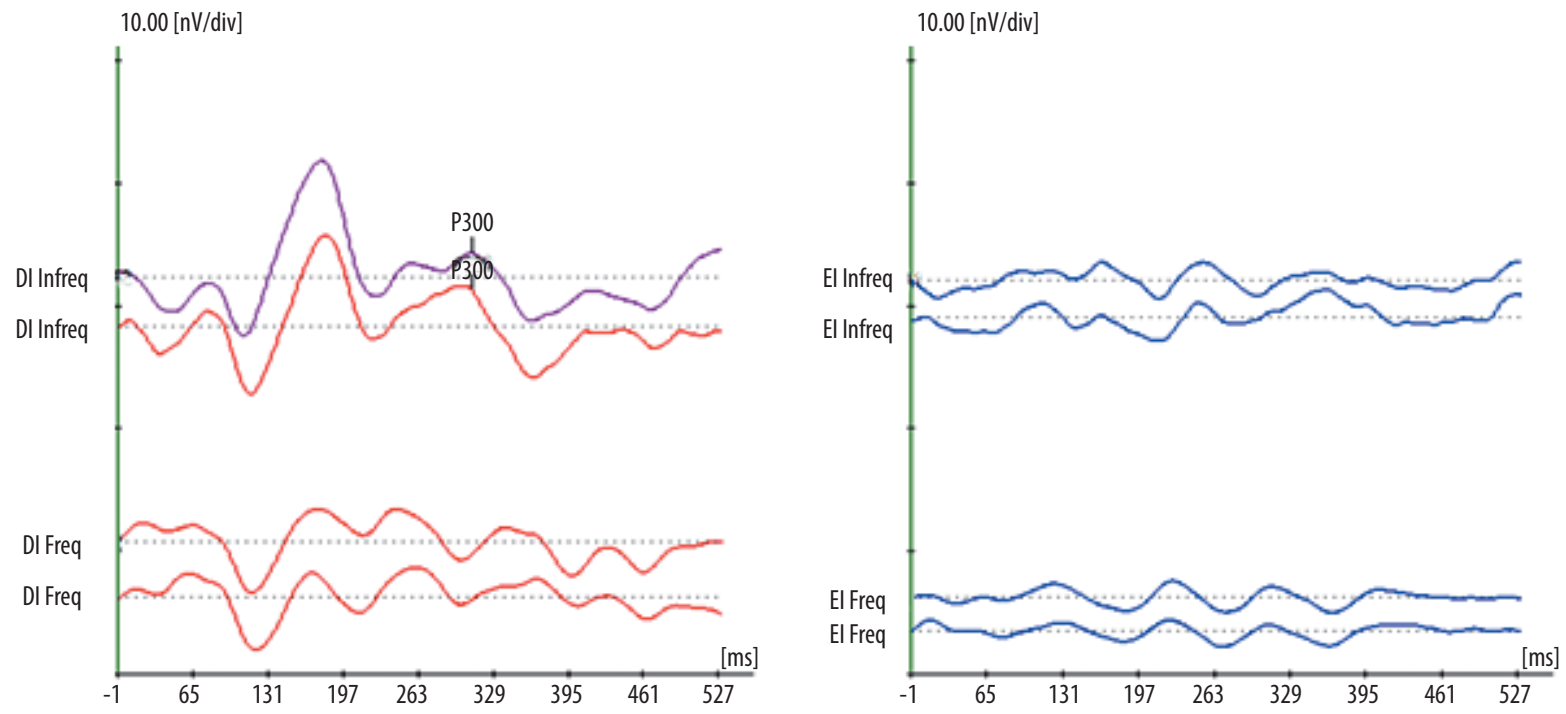

Figure 4. Long Latency Auditory Evoked Potentials (LLAEP) for the right ear (red) and left ear (blue)

Table 3. Parameters used for the electrophysiological tests

\begin{tabular}{lcccc}
\hline Parameter & ECochG & Click ABR & MLAEP & LLAEP \\
\hline Equipment & Biologic Navigator Pro & Biologic Navigator Pro & Biologic Navigator Pro & Biologic Navigator Pro \\
\hline Stimulated ear & RE/LE & RE/LE & RE/LE & RE/LE \\
\hline Type of stimulus & Click & Click & Click & Tone burst \\
\hline Polarity of stimulus & Alternating & Rarefaction & Rarefaction & Alternating \\
\hline Intensity of stimulus & $90 \mathrm{~dB} \mathrm{nHL}$ & $80 \mathrm{~dB} \mathrm{nHL}$ & $80 \mathrm{~dB}$ & $75 \mathrm{~dB} \mathrm{nHL}$ \\
\hline Rate of stimulus & $10.3 / \mathrm{sec}$ & $19.3 / \mathrm{sec}$ & $9.1 / \mathrm{sec}$ & $1.1 / \mathrm{sec}$ \\
\hline Number of scans & 1000 & 2000 & 1000 & 300 \\
\hline Filter (Hz) & $10-1500$ & $100-1500$ & $30-1500$ & $1-30$ \\
\hline Window & $10.66 \mathrm{~ms}$ & $10.66 \mathrm{~ms}$ & $106.6 \mathrm{~ms}$ & $533 \mathrm{~ms}$ \\
\hline Transducer & Insert ER-3A (Natus & Insert ER-3A & Insert ER-3A & Insert ER-3A \\
\hline Position of electrodes & TM electrode, A1 and A2 & Fz, A1, and A2 & $\mathrm{C1}, \mathrm{C2}$, Fpz, A1, and A2 & Cz, Fpz, Fz, A1, and A2 \\
\hline
\end{tabular}

Key: $R E$, right ear; $L E$, left ear; $m s$, milliseconds; sec, second; $A B R$, auditory brainstem response; MLAEP, middle latency auditory evoked potential; LLAEP, long latency auditory evoked potential 
confirmed by means of basic audiological testing (tonal and tympanometry with ipsi and contralateral reflexes). Hearing loss affects $24-81 \%$ of individuals who have undergone TBI due to trauma to the temporal bone $[17,18]$. Moreover, besides trauma in the temporal region, auditory alterations can be due to a number of reasons, such as: (i) perforation of the tympanic membrane; (ii) rupture of the oval window; (ii) rupture of the round window; (iii) ossicular discontinuity; (iv) displacement of the basilar membrane; (v) lesion of the hair cells of the cochlea; and (vi) degeneration of the auditory nerve [16]. Interestingly, profound sensorineural hearing loss is infrequent in TBI cases, reports indicating that the prevalence is less than $10 \%[17,19]$.

Electrocochleography showed no SP or AP responses for the left ear. It is known that patients with sensorineural hearing loss greater than $40-50 \mathrm{~dB}$ in the 1000 to $4000 \mathrm{~Hz}$ range are not good candidates for ECochG. The relationship between SP and AP is altered as the threshold increases $[20,21]$, which can affect the amplitude and area values. In addition, the reduction of amplitudes that tends to accompany hearing loss makes it difficult to identify and separate SP and AP in the extra-tympanic records. Finally, when hearing loss is greater than $60 \mathrm{~dB}$ above $500 \mathrm{~Hz}$, both components may not be registered by the TM, or at least so poorly defined that ECochG is ineffective for audiological diagnosis $[22,36]$.

For the Click Auditory Brainstem Response (Click ABR) evaluation, no response was observed for the left ear. This lack of response reflects a serious level of hearing loss. However, the literature reports a wide range of alterations in Click ABR responses, possibly due to different types, degrees, and locations of lesions resulting from TBI $[23,24]$. However, because Click ABR is an objective procedure and does not require the active participation of the patient, it can be extremely useful in audiological diagnosis. For this reason, the use of different assessment instruments should be employed in order to test the entire auditory pathway. In this case, Click ABR served as a good instrument for measuring the patient's baseline auditory condition, from which any alterations could be monitored.

The Middle Latency Auditory Evoked Potential (MLAEP) is the least used electrophysiological procedure in clinical practice. Nevertheless, it has the most value in testing patients who have suffered some kind of injury. MLAEP can evaluate the patient's cerebral and auditory function through a simple analysis of numerical values, and can be used to assess abnormalities in the central auditory nervous system. For example, MLAEP can predict functional outcomes after a craniotomy [25].

It is expected that in normal individuals the hemispheres will be symmetrical, so that the responses of the electrode positioned over the left hemisphere (C3) should be similar to the responses of the electrode positioned over the right hemisphere (C4). However, if an individual has some type of brain injury, the injured hemisphere will present reduced responses when compared to the other hemisphere; at the same time, if there is any hearing impairment, the impaired ear is expected to present reduced responses compared to the other ear [26]. In the present case, there was an absence of responses in $\mathrm{C} 1 \mathrm{~A} 1$ and $\mathrm{C} 2 \mathrm{~A} 1$; this shows an abnormal electrode effect, confirming a hemispheric lesion. Also, there was a response difference when comparing the pairs $\mathrm{C} 1 \mathrm{~A} 1 \times \mathrm{C} 1 \mathrm{~A} 2$ and $\mathrm{C} 2 \mathrm{~A} 1 \times \mathrm{C} 2 \mathrm{~A} 2$, demonstrating a change in the ear effect and evidence of left ear dysfunction.

Long Latency Auditory Evoked Potential (LLAEP) evaluation showed the presence in the right ear of the P300 cognitive potential, with values within the normal range, but there were no responses in the left ear. The absence of the P300 wave indicates profound sensorineural hearing loss. Interestingly, most studies that have recorded P300 waves in individuals with TBI find normal responses [27-29]. Nevertheless, the cognitive abilities of patients with TBI should be continuously monitored, since losses in processing speed, executive function, and attention can occur following injury [30].

Finally, tinnitus is one of the most intriguing and challenging pathologies, since it can have different generating sites, such as the inferior colliculus, geniculate body, primary auditory cortex, or temporal lobe [31-33]. Changes in any of these structures or regions can cause tinnitus. Therefore, the study of short, medium, and long latency potentials are of great importance in monitoring patients with tinnitus.

\section{Conclusion}

The present case study verifies the importance of assessing the peripheral and central auditory nervous system in cases of patients with a history of TBI. In view of the severity of the clinical condition of the patient affected by TBI, the hearing assessment was postponed, being carried out only after the patient's complaint of hearing loss. Thus, the present study reinforces the need for diagnosis and audiological monitoring in patients with severe TBI.

\section{Appendix}

\section{Glasgow coma scale}

The Glasgow Coma Scale (GCS) was described in 1974 by Teasdale and Jennett [9] as a way of communicating the level of consciousness of acute brain injury patients. The GCS is the most common scale used to describe a person's level of consciousness after TBI. Observation of a GCS score graph provides information that allows the monitoring of the patient's clinical evolution and guidance for changes in the treatment of head injuries.

The scale assesses the degree of stimulation necessary to obtain the best response based on three parameters: eye opening, verbal, and motor response. The analysis can be done based on the individual scores for each parameter or based on the final GCS score, which is the sum of these numbers and provides a summary of the overall situation.

The possible total values of CGS range from 3 to 15 , and it can be classified as severe ( 8 or less), moderate (9-12 points), or light (13-15 points).

According to medical reports, the patient in this case study arrived with a severe TBI of 8 points on the GCS. The score for each individual parameter was expressed as E2V3M3, 
being: (i) eye opening after fingertip stimulus (score 2); (ii) verbal response with intelligible single words (score 3); and (iii) best motor response was bends arm at elbow, features clearly predominantly abnormal (score 3 ).

\section{References}

1. Lew HL, Poole JH, Guillory SB, Salerno RM, Leskin G, Sigford B. Persistent problems after traumatic brain injury: the need for long-term follow-up and coordinated care. J Rehabil Res Dev, 2006; 43(2): vii-x.

2. Hyder AA, Wunderlich CA, Puvanachandra P, Gururaj G, Kobusingye OC. The impact of traumatic brain injuries: a global perspective. NeuroRehabil, 2007; 22(5): 341-53.

3. Anderson V, Catroppa C, Morse S, Haritou F, Rosenfeld J. Functional plasticity or vulnerability after early brain injury? Pediatrics, 2005 ; 116(6): 1374-82.

4. Sturzenegger M, Meienberg O. Basilar artery migraine: a followup study of 82 cases. Headache, 1985; 25: 408-15.

5. Lew H, Jerger J, Guillory S, Henry J. Auditory dysfunction in traumatic brain injury. J Rehabil Res Dev, 2007; 44: 921-8.

6. Abd al-Hady M, Shehata O, el-Mously M, Sallam F. Audiological findings following head trauma. J Laryngol Otol, 1990; 104. 927-36.

7. Marion M, Cevette M. Tinnitus. Mayo Clinic Proc, 1991; 66: 614-20.

8. White CL, Griffith S, Caron JL. Early progression of traumatic cerebral contusions: characterization and risk factors. J Trauma, 2009; 67(3): 508-14.

9. Teasdale G, Jennett B. Assessment of coma and impaired consciousness. A practical scale. Lancet, 1974; 2(7872): 81-4.

10. World Health Organization. Grades of hearing impairment, 2014. Available from: http://www.who.int/pbd/deafness/hearing_impairment_grades/en/index.html.

11. Coats AC. The summating potential and Meniere's disease. I Summating potential amplitude in Meniere and non-Meniere ears. Arch Otolaryngol, 1981; 107(4): 199-208.

12. Baba A, Takasaki K, Tanaka F, Tsukasaki N, Kumagami H, Takahashi H. Amplitude and area ratios of summating potential/action potential (SP/AP) in Meniere's disease. Acta Otolaryngol, 2009; 129(1): 25-9.

13. Musiek F, Lee W. Potenciais auditivos de média e longa latência. In: Musiek F, editor. Perspectivas atuais em avaliação auditiva. São Paulo: Manole; 2001, 239-67.

14. McPherson D. Late potentials of the auditory system. San Diego: Singular Publishing Group; 1996.

15. Cochran A, Scaife ER, Hansen KW, Downey EC. Hyperglycemia and outcomes from pediatric traumatic brain injury. J Trauma, 2003; 55(6): 1035-8.

16. Chiasson C. Traumatic Brain Injury (TBI): A primer for the hearing healthcare practitioner. Hearing Review, 2015; 22: 14.

17. Saraiya PV, Aygun N. Temporal bone fractures. Emerg Radiol, 2009; 16(4): 255-65.

18. Johnson F, Semaan M, Megerian C. Temporal bone fracture: evaluation and management in the modern era. In: Dornhoffer J, Chandra R, editors. Otolaryngologic Clinics of North America. Philadelphia: Elsevier Saunders; 2008, 597-618.
The scale is available translated into several languages, and can be found at https://www.glasgowcomascale.org.
19. Yetiser S, Hidir Y, Birkent H, Satar B, Durmaz A. Traumatic ossicular dislocations: etiology and management. Am J Otolaryngol, 2008; 29(1): 31-6.

20. Asai H, Mori N. Change in the summating potential and action potential during the fluctuation of hearing in Meniere's disease. Scand Audiol, 1989; 18(1): 13-7.

21. Mori N, Asai H, Sakagami M. The role of summating potential in the diagnosis and management of Meniere's disease. Acta OtoLaryngologica Suppl, 1993; 501: 51-3.

22. Ferraro JA. Electrocochleography: a review of recording approaches, clinical applications, and new findings in adults and children. J Am Acad Audiol, 2010; 21(3): 145-52.

23. Lindsay KW Carlin J, Kennedy I, Fry J, McInnes A, Teasdale GM. Evoked potentials in severe head injury: analysis and relation to outcome. J Neurol Neurosurg Psychiatry, 1981; 44: 796-802.

24. Scherg M, von Cramon D, Elton M. Brain-stem auditory-evoked potentials in post-comatose patients after severe closed head trauma. J Neurol, 1984; 231(1): 1-5.

25. Tsurukiri J, Nagata K, Hoshiai A, Oomura T, Jimbo H, Ikeda Y. Middle latency auditory-evoked potential index monitoring of cerebral function to predict functional outcome after emergency craniotomy in patients with brain damage. Scand J Trauma Resusc Emerg Med, 2015; 23(1): 80.

26. Kraus N, McGee T. The middle latency response generating system. Electroencephalogr Clin Neurophysiol, 1955; 44: 93-101.

27. Doi R, Morita K, Shigemori M, Tokutomi T, Maeda H. Characteristics of cognitive function in patients after traumatic brain injury assessed by visual and auditory event-related potentials. Am J Phys Med Rehabil, 2007; 86(8): 641-9.

28. Duncan CC, Kosmidis MH, Mirsky AF. Closed head injury-related information processing deficits: an event-related potential analysis. Int J Psychophysiol, 2005; 58(2-3): 133-57.

29. Elting JW, Maurits N, Weerden T, Spikman J, Keyser J, Naalt J. P300 analysis techniques in cognitive impairment after brain injury: comparison with neuropsychological and imaging data. Brain Inj, 2008; 22(11): 870-81.

30. Anderson V, Catroppa C, Morse S, Haritou F, Rosenfeld J. Functional plasticity or vulnerability after early brain injury? Pediatrics, 2005; 116(6): 1374-82.

31. Melcher JR, Sigalovsky IS, Guinan JJ, Levine RA. Lateralized tinnitus studied with functional magnetic resonance imaging: abnormal inferior colliculus activation. J Neuphysiol, 2000; 83(2): 1058-72.

32. Jastreboff PJ. Phantom auditory perception (tinnitus): mechanisms of generation and perception. Neurosci Res, 1990; 8(4): 221-54.

33. Shulman A. A final common pathway for tinnitus. The medial temporal lobe system. Int Tinnitus J, 1995; 1(2): 115-26. 